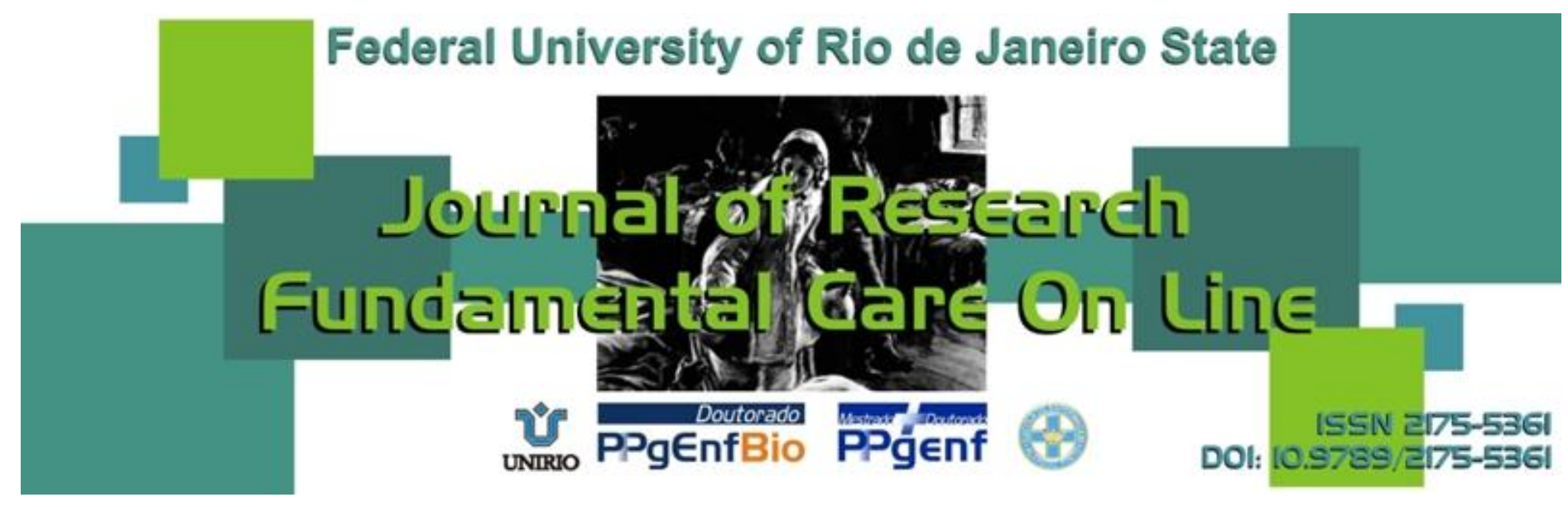

\title{
SYSTEMATIC REVIEW OF LITERATURE
}

UNVEILED THE LARVAL THERAPY AS ALTERNATIVE IN THE TREATMENT OF SKIN LESIONS: AN INTEGRATIVE REVIEW*

DESVELANDO A TERAPIA LARVAL COMO ALTERNATIVA NO TRATAMENTO DE LESÕES DE PELE: REVISÃO INTEGRATIVA

DESCUBRIENDO LA TERAPIA DE LARVAS COMO ALTERNATIVA EN EL TRATAMIENTO DE LESIONES DE LA PIEL: UNA REVISIÓN INTEGRADORA

Kauana Flores da Silva ${ }^{1}$, Mara Regina Caino Teixeira Marchiori

\begin{abstract}
Objective: to identify evidence in the literature in which the benefits of larval therapy provides patients with skin lesions through a systematic literature review in the form of an integrative review. Method: For search of articles and data analysis, we used two assessment tools. The survey was conducted between July 2009 and July 2010. Result: larval therapy was positive in most studies selected in relation to a rapid restoration of tissues such as the costs. Conclusion: the results presented have provided a better understanding of larval therapy and showed that, although there was no evidence of its use in Brazil, can be an effective option, especially when conventional treatments not working. Descriptors: Maggot, Flies, Wound Healing.
\end{abstract}

\section{RESUMO}

Objetivo: identificar nas evidências científicas da literatura quais os benefícios que a terapia larval proporciona aos pacientes com lesões de pele através de uma revisão sistemática da literatura, na modalidade de revisão integrativa. Método: para a busca dos artigos e a análise dos dados, foram utilizados dois instrumentos de avaliação. A pesquisa foi realizada entre julho de 2009 a julho de 2010. Resultado: a terapia larval mostrou-se positiva na maior parte dos estudos selecionados tanto em relação à restauração rápida dos tecidos como nos custos. Conclusão: os resultados apresentados proporcionaram um maior conhecimento sobre a terapia larval e mostraram que, apesar de não haver indícios de seu uso no Brasil, pode ser uma opção eficaz, principalmente quando os tratamentos convencionais não funcionam mais. Descritores: Larva, Moscas, Cicatrização de Feridas.

\section{RESUMEN}

Objetivo: identificar en evidencias en la literatura que los beneficios de la terapia con larvas a los pacientes con lesiones en la piel a través de una revisión sistemática de la literatura, en la forma de una revisión integradora. Método: Para la búsqueda de artículos y análisis de datos, se utilizaron dos instrumentos de evaluación. La encuesta fue realizada entre julio de 2009 a julio de 2010. Resultado: la terapia de larvas fue positiva en la mayoría de los estudios seleccionados en relación a una rápida restauración de los tejidos, tales como los costos. Conclusión: los resultados presentados proporcionan una mejor comprensión de la terapia larval y demostraron que, aunque no hay evidencia de su uso en Brasil, puede ser una opción eficaz, especialmente cuando los tratamientos convencionales han ya no funcionan. Descriptores: Larva, Moscas, La curación de heridas.

${ }^{1}$ Academic Nursing Center Franciscan University / UNIFRA / RS. E-mail: uanaflores@yahoo.com.br. Rua Atílio Munari, 68 Bairro João Goulart, Santa Maria, RS. (55)91619260. ²Nurse. PhD DINTER New frontiers UNIFESP / UFRJ / UFSM. Professor of Franciscan University Center / UNIFRA / RS. E-mail: Mara.marc@hotmail.com.

"Work titled Unveiling larval therapy as an alternative in the treatment of skin lesions: an integrative review, presented to the Nursing Course Franciscan University Center (UNIFRA) for Completion of Undergraduate Nursing in 2010. 


\section{INTRODUCTION}

The skin lesions are increasingly frequent in various regions of the world, and this is due to the increased number of individuals with chronic illnesses and predisposing the development of lesions, such as diabetes. Of the more than 150 million diabetics worldwide, $15 \%$ present wounds throughout his life. ${ }^{1}$

As the skin lesions are common and often difficult to cure, several techniques have been used to aid in the healing of these lesions, but treatments are expensive, time consuming and not always effective. $^{1}$

The larval therapy (TL), also known as biotherapy or biosurgery involves the application of larvae of some species of flies in skin lesions with the aim of restoring the fabric. Alternative therapies have been used by humans at different periods of human history. The practice of using larvae of certain insects, has been the subject of experimental research on skin lesions and recognition as therapy in wound healing, as well as its benefits have accounts in books and periodicals. $^{1}$

There are reports on research into the use of larval therapy in Autralia and Mayan tribes in Central America where wounds healed in a few days. It was also observed in wars, because the large number of casualties and the difficulties in treating several soldiers with wounds infested with maggots and had the best outcome. ${ }^{1}$

In 1557, Ambroise Paré noted that the larvae infest the wounds of the soldiers, but did not consider its advantages and only withdrew injuries. Besides this, Dominic Larrey found that infested wounds progressed better than the uninfected. ${ }^{1}$

In the Western context, Zachary John Forney, was the first to introduce larvae in wounds, noting that the larvae in a single day R. pesq.: cuid. fundam. online 2013. jul./set. 5(3):66-74 would clean a wound much better than any means at our disposal, and who saved many lives by their use. $^{1}$

The larval therapy had its heyday between the world wars with William Baer, U.S. Army surgeon, who noted that soldiers whose wounds had maggots injury recovery progressed better than those without maggots. His records and studies showed that soldiers who had stayed for a week on the battlefield unattended no evidence of systemic infection, pus or fever and that his injuries had visible pink granulation tissue. Unfortunately, the larvae were not sterile and some of his patients contracted tetanus and erysipelas. Apart from these, no other serious consequence was reported. ${ }^{1}$

In 1920 Baer developed a method to sterilize the larvae, contributing to the success and popularity of the technique. Treated with this method four children with osteomyelitis, before incurable, succeeding in all cases, which prompted him to use it more broadly. Thus, larval therapy became widely used in the United States in the 1930 s. $^{1}$

In the mid 40s, with the advent of antibiotics and innovative surgical techniques, larval therapy practically no longer used. However, in 1980, Ronald A. Sherman, a doctor of the University of California began to improve and apply the technique in patients with chronic injuries due to resistance to many antibiotics and the limited efficacy of conventional treatments which, besides being expensive, did not prevent severe consequences such as amputation.

The experimental studies using the larval therapy have shown that this technique is capable of cleaning wounds and fight infection much faster than otherwise used, making it ideal for initial treatment of all types infected or necrotic wounds without consider the etiology and subsequent treatment. 
Silva KF, Marchiori MRCT.

In Brazil, few studies are conducted on larval therapy in the treatment of skin lesions, some research centers in the central-south of the country are developing experimental studies in this area of knowledge, still in its incipient results and application in humans. So, the question is: on the need to expand the knowledge and the search for publications in national and international journals on this subject, to reconnect the various forms of healing that nature provides leading man closer to his natural principles and the revaluation of this relationship. Given this questioning has for research question: what are the benefits mentioned in surveys conducted with the use of larval therapy in patients with skin lesions?

This study aimed to identify the scientific evidence of the benefits that larval therapy gives patients with skin lesions.

\section{METHODOLOGY}

A Figura 1 apresenta o fluxograma da coleta de dados e a seleção dos estudos.

This is a study of a systematic review of scientific literature on modality called integrative review.

The integrative review (IR) follows a rigorous method of search, selection and evaluation of the relevance and validity of the research found. Provides comprehensive information about a particular event interconnecting isolated elements of existing studies. The RI includes qualitative and quantitative research, allowing for a summary of previous studies and reach conclusions on the topic of interest. ${ }^{2}$

The integrative review is divided into five stages: problem formulation, data collection, evaluation of collected data, analysis and interpretation of data and presentation of results.

The first stage consisted of the formulation of the question where problem should identify the R. pesq.: cuid. fundam. online 2013. jul./set. 5(3):66-74
Unveiled the larval therapy...

purpose of the review in a clear and specific.In the second stage was conducted to collect data, defining the criteria for inclusion and exclusion of studies, strategies and databases used in the search, justifying all the criteria. For the present study we used databases, electronic journals and national and international bibliographic references.

The third step was the evaluation of the data set, where the researcher was critical to determine what procedures used to assess the selected studies and find that the evidence allowed. It was necessary a tool to assess and highlight the data. Together, we chose to use a second methodological assessment tool for greater methodological rigor of the studies selected and thus get the quality of the findings.

The analysis and interpretation are part of the fourth stage, where it was extracted from a synthesis researched articles and performed their comparison with theoretical knowledge and defining priorities for future research. ${ }^{3}$

The fifth step refers to the presentation of results through a summary of each article followed by discussion, offering the reader, explaining the important findings and possible gaps and trends in research. $^{3}$

To guide this study was formulated the question: "what are the benefits mentioned in surveys conducted with the use of larval therapy in patients with skin lesions?".

Due to the small amount of information available, especially at the national level, the source of search data bases were used in general usual systematic review on health and related areas.

For the present work the following databases and electronic journals: Virtual Health Library (VHL), Latin American and Caribbean Health Sciences (LILACS) and International Literature on Health Sciences (MEDLINE). 
Silva KF, Marchiori MRCT.

The survey of studies was conducted during the second half of 2009.

Inclusion criteria adopted to guide the search and selection of articles were studies that addressed the issue of larval therapy used to treat skin lesions published from 1999 to 2009, with a qualitative, quantitative or qualitativequantitative and national and international publications, in English, Spanish or Portuguese.

Exclusion criteria were articles without access to full text databases in general and electronic journals, articles not available online and no evidence that data on the subject proposal.

The strategy used in order to retrieve relevant studies to the research question of this research was to access the databases and electronic journals by VHL, using the term larval therapy option in the "integrated". After reading the titles and abstracts of all publications found in the search strategy was limited to only those conducted with humans and to produce the desired inclusion criteria. Where the title and summary were not enough to set your selection, we sought to publish in full.

After exhaustive search in databases, 10 articles were found, but three of these did not have the complete text available online, and then discarded.

Although visible difficulty finding full articles about larval therapy, the strategy provided a broad search of all relevant studies and after its completion, were pre-selected seven articles.

For the selection of studies was carried out in full translation of the same reading and to evaluate the area of interest in the study and establish the connection to the research question. The seven remaining articles found in the search.

Each selected study received a number in order from 1 to 7 with the aim of facilitating the identification of articles through this coding.

R. pesq.: cuid. fundam. online 2013. jul./set. 5(3):66-74
Unveiled the larval therapy...

Then we proceeded to carefully read the study in full, to highlight the criteria for inclusion and exclusion. At this stage occurred consensus meetings with the supervisor of the research to clarify doubts regarding these criteria. This procedure aims to reduce bias in selection of studies, giving it greater security. The seven items constituted the sample.

To extract the necessary data regarding the research question, we used an instrument consisting of 19 items, including the identification of the study, its methodology and results. Then there was the exhaustive reading of selected articles to identify the items of the instrument expressed or implied and select the parts that made up the scientific evidence and thus provide the basis for answering the research question.

The interpretation and analysis of data were outlined by the instruments of data collection and analysis, where the extracted data from all selected articles were deposited in a large frame for better visibility and thus get the gist of each article, foundations seeking to reach the goal of study.

Was sought, found in articles, data that represented the feasibility study and, preferably, to present experimental research for better understanding of larval therapy and its actual benefits to the patient.

Figure 1 shows the flowchart of data collection and selection of studies.

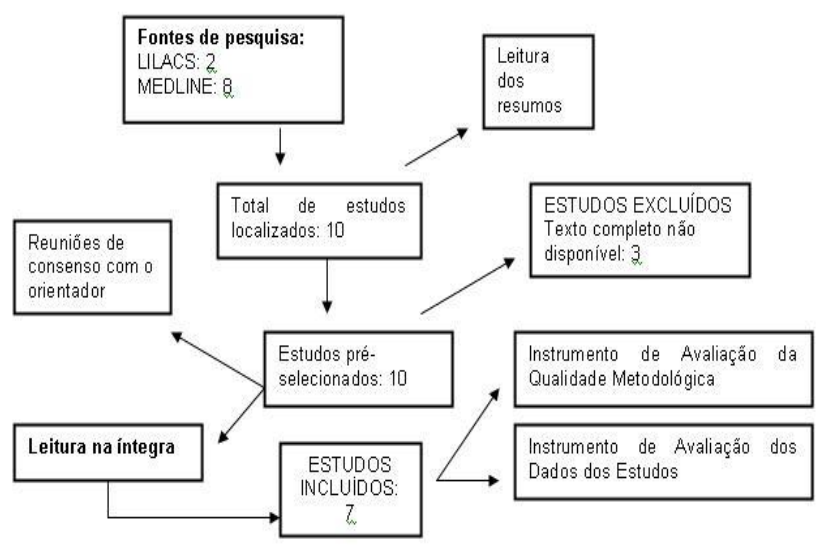

Figure 1. Fluxogram of data collection and selection of studies 
Table 1. Characterization of studies

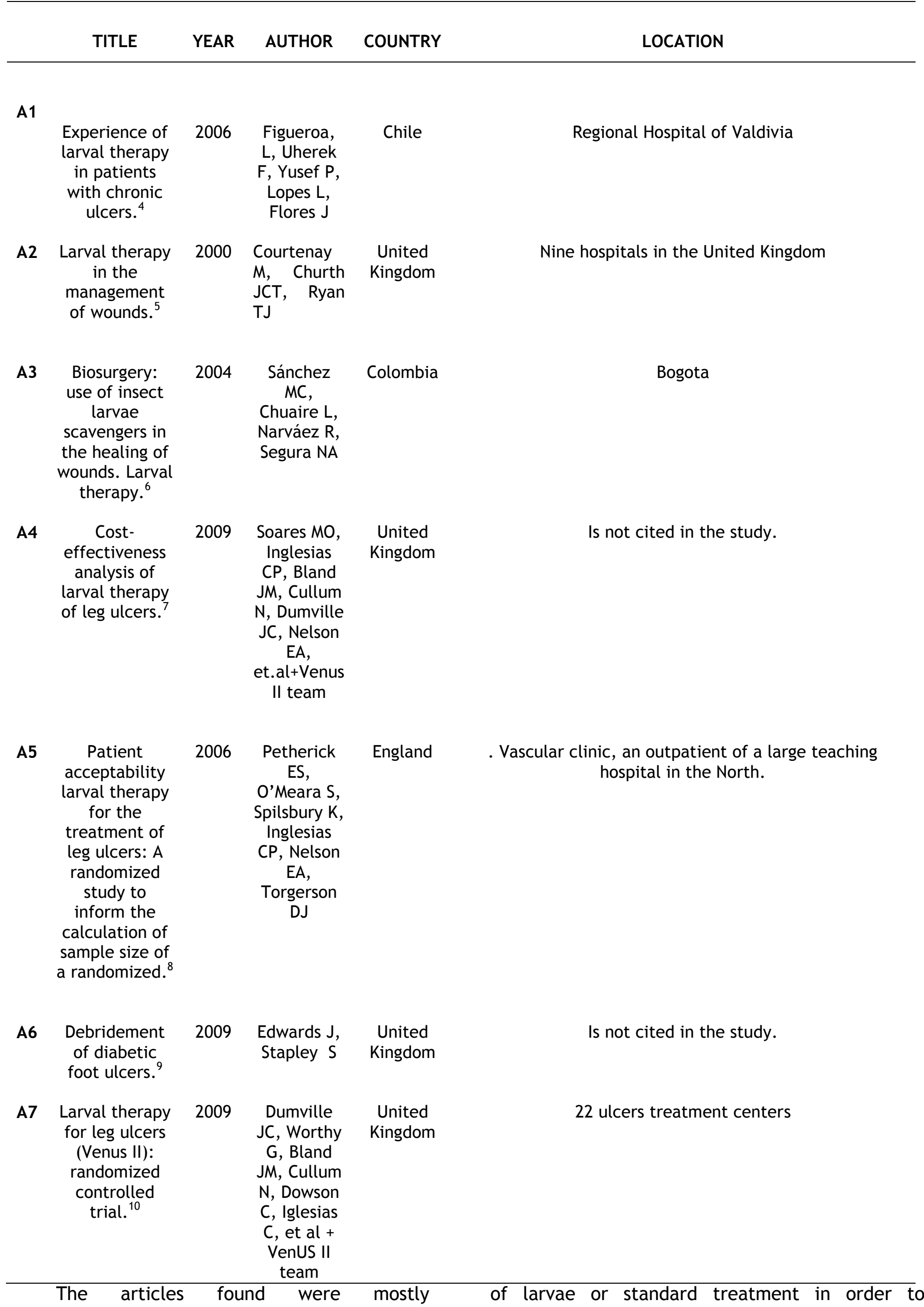
experimental studies used where the application achieve the ultimate goal.

R. pesq.: cuid. fundam. online 2013. jul./set. 5(3):66-74 
Table 2. Summary of studies

\section{OBJECTIVES}

A1 Play the good results obtained in other countries, reducing treatment time of chronic wounds. Unscented and lesions that evolve with dressings, grafts spontaneous healing.

A2 Analyze the current use of the $T L$ in the United Kingdom, providing some guidance on best practices. TL.

A4 . Evaluate the costeffectiveness of TL compared with hydrogel in the management of leg ulcers.

\section{OBJECTIVES}

A5 Determine acceptability of the patient to $T L$ and get the healing time required for patients accepted this technique rather than the standard treatment.

A6 Assess evidence for the efficacy of the debridement as a treatment for diabetic foot ulcers.
Recruited nine patients 70 hospitals that applied TL and the data were collected by the nurses of hospitals, through questionnaire and research on documents of patients.

Bibliographical study.

Applied methods in patients who were divided into three groups: loose, bagged larvae or hydrogel with the help of experienced nurses at TL.

\section{METHODOLOGY}

Used questionnaires applied by nurses to 35 patients with leg ulcers and with 18 years of age or older.
The total cleaning of the lesions, the disappearance of the stench and secretion, the presence of granulation tissue and reducing the size of the lesion.

Reduction of hospital stay, surgery, the size of the lesion, the necrotic tissue, exudate quantity, the stench and the pain, as well as the granulation area increase and stopping the use of antibiotics.

The larvae Act removing the necrotic tissue, stimulating the granulation tissue and removing microorganisms.

They noted that nursing consultations were the main driver of the total costs, that treatment with maggots cost an average $\mathrm{R} \$ 254,00$ more per patient than the Hydrogel and they healed 2.42 days before the standard treatment, but the findings described were not significant.

\section{RESULTS}

The authors reported that $77 \%$ of respondents would consider a TL and that no reduction in healing time would be required for this to happen.

The author notes that the Hydrogel is the best option in the healing of ulcers and the common result was the complete healing. Yet all the studies assessed failed and were of poor quality.
A7 Evaluate the effect of TL on wound healing, where the participants had venous leg ulcers or mixed, with at least $25 \%$ necrotic tissue
A review of studies in data base through the questions: did the debridement increases the healing of diabetic foot? If Yes, then what are the most effective methods, faster, more cost efficient and acceptable to the patient? Among the articles included, compared the effectiveness of larvae with the Hydrogel, which for the author, was abstract and presented no significant difference between the two treatments.

Data collection was done by nurses through observation of ulcers and questionnaires, the participants divided to receive loose larvae, bagged or hydrogel.
The authors observed that the larvae unbridled the wound in a time less than the Hydrogel, which the bacterial load was not difference between the two methods and that pain reported by some patients is transient and does not interfere with quality of life.

R. pesq.: cuid. fundam. online 2013. jul./set. 5(3):66-74 


\section{RESULTS AND DISCUSSION}

Through analysis of the literature were identified benefits of TL as debridement, the bactericidal action, the time required for curing and the cost compared with conventional treatments.

With the study of larval therapy three aforementioned authors obtained the same results with regard to the benefits of this practice. ${ }^{1-3}$

The study conducted cost-effectiveness, proved to be the TL expensive, compared with standard treatment, causing controversy in the literature, describing this as a method significantly cheaper than the others. ${ }^{7,1}$

Two of the articles, by highlighting that the larvae can be applied in clinics and has bactericidal same bacteria resistant to antibiotics, come to the meeting says that the author of $\mathrm{A} 1^{(2,3,1)}$. Already, one of the authors go against this finding, therefore, with the conclusion of her study, noted that the difference in killing bacteria between the two treatments is statistically insignificant. $^{7}$

Of the seven selected articles, demonstrate that only two therapy larval does not contribute to the healing of injuries in proportions higher than those used in large scale treatment, however admit failures during the study. 4,6

It was felt, in reading the articles, that there was a considerable refusal by patients regarding the use of maggots to treat their injuries.

Although all the benefits of TL, some of the articles studied left gaps in many aspects, such as the acceptance by the ethics committee because some one is dealing with human research, others do not report the methodology used clearly. One of the studies also did not possess allowances for scientific purposes since, as a review, did not get enough data for conclusive results to the research findings because of poor quality and many suggest further research on the subject.

One article quotes found using this technique in Brazil, but were not found evidence to confirm its applicability in the treatment of skin lesions.

\section{CONCLUSION}

The flies are considered as being harmful and repulsive to most people, and indeed some are. However, the vast majority of opinion would change if their benefits were widespread.

Although the $T L$ is not employed in Brazil studies show the advantages and benefits of your practice, widely used in many countries.

The results shown in different studies showed that this ancient technique used as practice can contribute to the healing of skin lesions where conventional treatment is no longer an effective alternative.

With regard to cost, most of the items questioned, the therapy is similar to the standard procedures adopted in the country, this study revealed that, as it is superior to the quality of life provided to the patient, so the importance of knowledge and the incentive to developing countries.

The culture of the population is not able to accept the $T L$, perhaps due to the relation of flies to dirt or outdated, but which makes the introduction of this technique in the country, avoiding disclosure and investment in experimental research in this area, is the power of the pharmaceutical industry, due to the advantages of cost effectiveness that the larvae causes the patient and to those who use them.

Another important point was the method adopted for the study that provided a great learning experience for performing, in a systematic way, a synthesis of knowledge on a 
Silva KF, Marchiori MRCT.

given subject and the possible application of this study in practice.

Because existing studies present restrictions, realized the need for further research on the subject, especially as compared with other therapies, because the availability of more effective results and defined on the TL will help improve its image in society and health professionals. It is expected that in Brazil, nursing professionals, who have greater contact with the patient and his suffering, realize the importance of a better understanding of alternative therapies and encourage, through research initiatives and the application of larvae on injuries skin.

This study, in addition to unveiling the benefits of an unconventional therapy provides the challenge to understand, discuss, and find, why not apply this simple and effective technique in the treatment of skin lesions and thus offer society an opportunity to achieve a better quality of life.

\section{REFERENCES}

1. Marcondes Carlos B. Terapia Larval de lesões de pele causadas por diabetes e outras doenças. Florianópolis (SC): Ed. da UFSC; 2006. 88 p.

2. Toledo, Melina M. Vulnerabilidade de adolescentes ao HIV/AIDS: Revisão integrativa. [dissertação de mestrado]. São Paulo (SP): Escola de Enfermagem da Universidade de São Paulo; 2008. $153 \mathrm{p}$.

3. Cooper, HM. Scientific Guidelines for Conducting Integrative Research Reviews. Rev Educ Res . [periódico na Internet]. 1982 [acesso 20 jul 2009];. 52(2):291-302. Inglês. Disponível em: http://rer.sagepub.com/search/results?fulltext=c ooper\&submit=yes\&journal_set=sprer\&src=selecte d\&andorexactfulltext=and
Unveiled the larval therapy...

4. Figueroa L, Uherek F, Yusef P, Lopez L, Flores J. [Experiencia de terapia larval en pacientes con úlceras crônicas]. Parasitol Latinoam . [periódico na Internet]. 2006. [acesso 20 set 2009]; 61(3/4): 160-64. Espanhol. Disponível em: http: / / www.scielo.cl/scielo.php?script=sci_arttex t\&pid=S0717-77122006000200010\&lang=pt

5. Courtenay M, Churth JCT, Ryan TJ. [Larva therapy in wound management]. Jornal of the Royal Soc Medicine . [periódico na Internet]. 2000 [acesso 15 set 2009]; 93:72-4. Inglês. Disponível em:

http://www.ncbi.nlm.nih.gov/pmc/articles/PMC1 288068/?tool=pubmed

6. Sánchez MC, Chuaire L, Narváez R, Segura NA. [Biocirugía: utilización de larvas de insectos necrófagos en la curación de heridas. La terapia larval]. Ver Cienc Salud. (Colombia) . [periódico na Internet]. 2004 [acesso 22 set 2009]; 2(2): pg. 156-164. Espanhol. Disponível em: http: / / pesquisa.bvsalud.org/regional/resources/li l-440153

7. Soares MO, Iglesias CP, Bland JM, Cullum N, Dumville JC, Nelson EA, et al. + Vênus II team. [Cost effectiveness analysis of larval therapy for leg ulcers]. BMJ . [periódico na Internet]. 2009 [acesso 22 set 2009]; 338:b825. Inglês. Disponível em:

http://www.ncbi.nlm.nih.gov/pmc/articles/PMC2 659856/?tool=pubmed

8. Petherick ES, O'meara S, Spilsbury K, Iglesias CP, Nelson EA, Torgerson DJ. [Patient acceptability of larval therapy for leg ulcer treatment: a randomised survey to inform the sample size calculation of a randomised trial]. BMC Méd Res Methodol. [periódico na Internet]. 2006 [acesso 20 set 2009]; 6:43. Inglês. Disponível em: 
http: //www.ncbi.nlm.nih.gov/pmc/articles/PMC1

$569430 /$ ?tool=pubmed

9. Edwards J, Stapley S. [Debridement of diabetic foot ulcers]. Cochrane Database of Systematic Reviews. In: The Cochrane Library [Internet]. 2002 [acesso 21 set 2009]; Issue 3, art. n CD003556. Inglês. Disponível em: http://www.ncbi.nlm.nih.gov/pubmed/12519603

10. Dunville JC, Worthy G, Bland JM, Cullum N, Dowson C, Iglesias C, et al. + Vênus II team. [Larval therapy for leg ulcers (VenUS II): randomised controlled trial]. BMJ [Internet]. 2009 [acesso 02 ago 2009]; 338:B773, 2009. Inglês. Disponível em: http: //www.ncbi.nlm.nih.gov/pmc/articles/PMC2 659858/?tool=pubmed

Received on: 25/06/2012

Reviews required: Não

Approved on: 18/01/2013

Published on: 01/07/2013

R. pesq.: cuid. fundam. online 2013. jul./set. 5(3):66-74 